\title{
Effect of acidification on an Arctic phytoplankton community from Disko Bay, West Greenland
}

\author{
Christina Thoisen ${ }^{1,2, *}$, Karen Riisgaard ${ }^{3}$, Nina Lundholm ${ }^{4}$, Torkel Gissel Nielsen ${ }^{3,5}$, \\ Per Juel Hansen ${ }^{2}$
}

\footnotetext{
${ }^{1}$ Department of Environmental, Social and Spatial Change, Roskilde University, Universitetsvej 1, 4000 Roskilde, Denmark ${ }^{2}$ Centre for Ocean Life, Marine Biological Section, University of Copenhagen, Strandpromenaden 5, 3000 Helsingør, Denmark ${ }^{3}$ National Institute of Aquatic Resources, DTU Aqua, Section for Ocean Ecology and Climate, Technical University of Denmark, Kavalergården 6, 2920 Charlottenlund, Denmark

${ }^{4}$ Natural History Museum of Denmark, University of Copenhagen, Sølvgade 83S, 1307 Copenhagen K, Denmark

${ }^{5}$ Greenland Climate Research Centre, Greenland Institute of Natural Resources, Kivioq 2, PO Box 570, 3900 Nuuk, Greenland
}

\begin{abstract}
Long-term measurements (i.e. months) of in situ $\mathrm{pH}$ have not previously been reported from the Arctic; this study shows fluctuations between $\mathrm{pH} 7.5$ and 8.3 during the spring bloom 2012 in a coastal area of Disko Bay, West Greenland. The effect of acidification on phytoplankton from this area was studied at both the community and species level in experimental $\mathrm{pH}$ treatments within $(\mathrm{pH}$ 8.0, 7.7 and 7.4) and outside $(\mathrm{pH}$ 7.1) in situ $\mathrm{pH}$. The growth rate of the phytoplankton community decreased during the experimental acidification from $0.50 \pm 0.01 \mathrm{~d}^{-1}$ (SD) at $\mathrm{pH} 8.0$ to $0.22 \pm 0.01 \mathrm{~d}^{-1}$ at $\mathrm{pH} 7.1$. Nevertheless, the response to acidification was speciesspecific and divided into 4 categories: I, least affected; II, affected only at $\mathrm{pH} 7.1$; III, gradually affected and IV, highly affected. In addition, the colony size and chain length of selected species were affected by the acidification. Our findings show that coastal phytoplankton from Disko Bay is naturally exposed to $\mathrm{pH}$ fluctuations exceeding the experimental $\mathrm{pH}$ range used in most ocean acidification studies. We emphasize that studies on ocean acidification should include in situ $\mathrm{pH}$ before assumptions on the effect of acidification on marine organisms can be made.
\end{abstract}

KEY WORDS: Ocean acidification $\cdot$ Coastal $\cdot$ Arctic phytoplankton $\cdot$ Growth rate $\cdot \mathrm{pH} \cdot \mathrm{CO}_{2} \cdot \mathrm{DIC}$

\section{INTRODUCTION}

The impacts of ongoing ocean acidification on marine organisms are a highly debated topic within the scientific community. Anthropogenic emissions are expected to increase the level of atmospheric $\mathrm{CO}_{2}$ from $\sim 280 \mathrm{ppm}$ in the mid-18 $8^{\text {th }}$ century to $\sim 700 \mathrm{ppm}$ by the end of the $21^{\text {st }}$ century (Riebesell et al. 2009). Approximately $25 \%$ of the emitted atmospheric $\mathrm{CO}_{2}$ is absorbed into the oceans (Riebesell et al. 2010) where chemical reactions alter the composition of dissolved inorganic carbon (DIC) while lowering $\mathrm{pH}$ (acidification). The average $\mathrm{pH}$ of ocean surface waters is expected to decrease from $~ 8.2$ in the mid- $18^{\text {th }}$ century to $\sim 7.8$ by the end of the $21^{\text {st }}$ century (Feely et al. 2009). When $\mathrm{pH}$ of seawater decreases, the concentration of $\mathrm{CO}_{3}{ }^{2-}$ (carbonate ion) also decreases, while $\mathrm{HCO}_{3}{ }^{-}$(bicarbonate ion) remains in vast concentrations (for details on seawater carbonate chemistry see Zeebe \& Wolf-Gladrow 2003). The majority of phytoplankton examined in the literature utilize both $\mathrm{HCO}_{3}{ }^{-}$and $\mathrm{CO}_{2}$ for photosynthesis, while some use either $\mathrm{HCO}_{3}{ }^{-}$or $\mathrm{CO}_{2}$ (e.g. Giordano et al. 2005). Increased $\mathrm{CO}_{2}$ could potentially increase primary production, especially for species relying on diffuse uptake of $\mathrm{CO}_{2}$ since the energy usage for the uptake of inorganic carbon through carbon concentrating mechanisms (CCMs) is likely to be reduced 
(Rost et al. 2008). However, extracellular $\mathrm{pH}\left(\mathrm{pH}_{\mathrm{e}}\right)$ may influence the intracellular $\mathrm{pH}\left(\mathrm{pH}_{\mathrm{i}}\right)$ of unicellular organisms and affect physiological processes such as ion transport, enzyme activity, protein function and nutrient uptake (Gattuso \& Hansson 2011 and references therein, see also Nimer et al. 1994). Thus, increased $\mathrm{CO}_{2}$ may not result in enhanced primary production if other physiological processes are affected negatively by acidification.

The formation of chains and colonies in marine phytoplankton is well known. For diatoms, it is presumed that this reduces sinking velocity and predation, and increases sexual reproduction (Smayda \& Bolelyn 1966, Takabayashi et al. 2006, Kooistra et al. 2007, Bergkvist et al. 2012). Likewise, the prymnesiophyte Phaeocystis globosa forms different sized colonies depending on the type of grazer present (Jakobsen \& Tang 2002). The effects of acidification on the formation of chains and colonies have, to our knowledge, not been studied until now. Considering that acidification affects physiological processes, it is likely that these formations are affected.

Ocean $\mathrm{pH}$ is considered stable on seasonal and diurnal scales due to the buffering capacity of seawater, with an average open ocean surface $\mathrm{pH}$ of $\sim 8.2$ (Feely et al. 2009). This stability in $\mathrm{pH}$ is particularly true for open oceans where algal biomass is usually low. In contrast, $\mathrm{pH}$ in coastal ecosystems can exhibit large seasonal and diurnal fluctuations shaped by factors such as photosynthesis, respiration, upwelling, $\mathrm{CO}_{2}$ venting, trophic state and water residence time (e.g. Feely et al. 2008, Wootton et al. 2008, Hofmann et al. 2011, Duarte et al. 2013). Seasonal variations in $\mathrm{pH}$ levels in temperate coastal ecosystems correlate with productivity, and the fluctuation decreases with distance from the shore (Provoost et al. 2010). In shallow and temperate coastal areas, the pH can vary from 7.4 to 9.2 on a diurnal basis (Middelboe \& Hansen 2007), and in the Danish eutrophic Mariager Fjord, the minimum and maximum $\mathrm{pH}$ during a 10 yr period was $\sim 7.1$ and $\sim 9.7$, respectively (Hansen 2002). Smaller fluctuations in the range of 0.1 to $\sim 0.6 \mathrm{pH}$ units were measured in inner Danish waters over 6 decades (Duarte et al. 2013), and yearly fluctuations of $\mathrm{pH}$ in the western Gulf of Finland regularly spanned $1 \mathrm{pH}$ unit (Brutemark et al. 2011). Studies on natural fluctuations of $\mathrm{pH}$ have focused on temperate coastal waters, and studies on the tolerance of phytoplankton to acidification have primarily dealt with temperate phytoplankton (e.g. Lundholm \& Hansen 2004, Kim \& Lee 2006, Berge et al. 2010, Lohbeck et al. 2012, McCarthy et al. 2012). Unfortunately, the majority of studies on the effect of acidifi- cation has been conducted in the $\mathrm{pH}$ range 7.7 to 8.2 , despite the fact that natural fluctuations of $\mathrm{pH}$ are much greater in coastal areas and often decrease to $<7.7$ (e.g. Hansen 2002, Hofmann et al. 2011). To obtain compelling results regarding effects from ocean acidification, measurements of natural $\mathrm{pH}$ fluctuations in a given area are needed to experimentally expose organisms to $\mathrm{pH}$ values beyond present-day naturally occurring levels.

The Arctic Ocean is presumed to be very sensitive to ocean acidification due to the high solubility of $\mathrm{CO}_{2}$ in cold water and the decreasing sea ice cover (Slagstad et al. 2011). However, only short-term measurements (over days) of $\mathrm{pH}$ levels in the polar open ocean and in the brine of sea ice have been conducted (e.g. Gleitz et al. 1995, Hofmann et al. 2011). Short-term measurements do not provide thorough insight into the $\mathrm{pH}$ fluctuations that organisms are exposed to over a longer time scale. It is hereby crucial to collect in situ $\mathrm{pH}$ data in the Arctic region during long-term measurements (over months). This will allow for a more qualified study on the effects of acidification on Arctic organisms, and contribute to a better estimate of the impact of ocean acidification in the Arctic region.

The aim of the present study was to monitor the long-term fluctuations of in situ pH levels in a coastal water column during the Arctic phytoplankton spring bloom while examining the effect of acidification on phytoplankton growth via incubations with natural phytoplankton assemblages exposed to different $\mathrm{pH}$ levels.

\section{MATERIALS AND METHODS}

\section{Study site}

The experiment was conducted in spring 2012 at Arctic Station (University of Copenhagen, Denmark) in Qeqertarsuaq on Disko Island, West Greenland (Fig. 1). A few days after the breakup of sea ice (April 14) the plankton community in Disko Bay was collected from the R/V 'Porsild' at a $300 \mathrm{~m}$ deep monitoring station (69 $13 \mathrm{~N}, 53^{\circ} 22 \mathrm{~W}$ ) outside of Qeqertarsuaq. Depth distribution of salinity and temperature was recorded with a Seabird CTD every $3^{\text {rd }}$ day and samples for $\mathrm{pH}$ measurements were collected at depths of 1, 40, 50, 75, 100, 150, 200 and $250 \mathrm{~m}$ with a Niskin bottle. The plankton community was collected using a 101 Niskin bottle from the depth of the chlorophyll maximum (5 $\mathrm{m}$ depth) and the sample was reverse-filtered into a 251 container via a silicon tube 

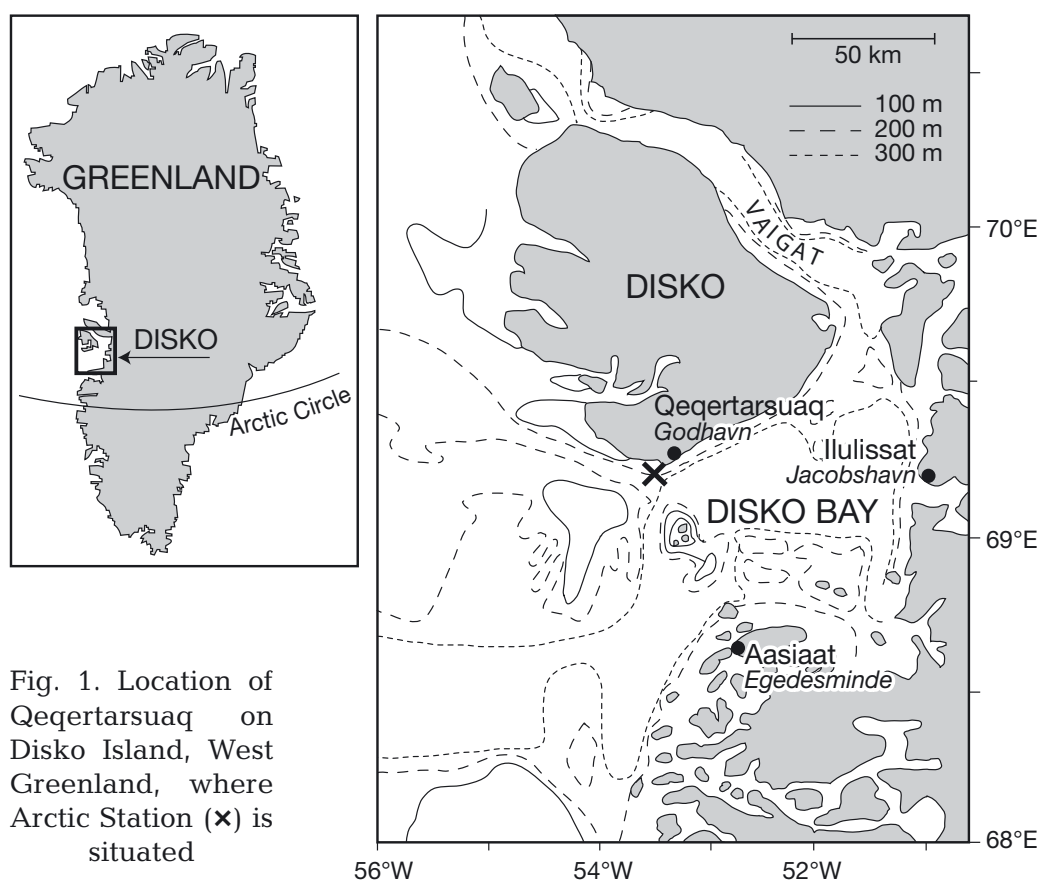

Fig. 1. Location of Qeqertarsuaq on Disko Island, West Greenland, where Arctic Station $(\mathbf{x})$ is situated

through a cylinder with a $250 \mu \mathrm{m}$ nylon mesh to remove mesozooplankton. Immediately after filtration, the plankton assemblage was carefully mixed and transferred to 12 incubation bottles via a silicon tube.

\section{Seawater for dilution}

Seawater used for diluting the treatments during the experiment was collected from the sampling station below the pycnocline (150 to $200 \mathrm{~m}$ ) to ensure nutrient-rich water. The water was filtered through a $0.45 \mu \mathrm{m}$ Whatman ${ }^{\circledR}$ polycap filter and stored dark and cold $\left(3 \pm 2{ }^{\circ} \mathrm{C}\right)$ in $25 \mathrm{l}$ containers. Average $\mathrm{pH}$, temperature and salinity of the seawater were $7.9 \pm$ $0.1,3.3 \pm 0.1{ }^{\circ} \mathrm{C}$ and $34.3 \pm 0.0$, respectively. AU values are $\pm \mathrm{SD}$.

\section{Experimental setup and $\mathrm{CO}_{2}$ manipulation}

The experiment was run in triplicated 11 Nalgene ${ }^{\circledR}$ polycarbonate bottles and $\mathrm{pH}$ was adjusted by applying gaseous $\mathrm{CO}_{2}$ (UN 1013 Carbon dioxide, Class 2, 2A, ADR; Air Liquide Denmark). The incubation bottles were filled to capacity (1.23 l), allowing no headspace in order to avoid fluctuations of seawater chemistry as well as avoiding negative effects of air bubbles on protists; the top was then sealed with parafilm before applying the lid. Triplicate bottles of
4 treatments $(\mathrm{pH} 8.0,7.7,7.4$ and 7.1$)$ were placed at $3 \pm 2^{\circ} \mathrm{C}$ on a flat turning plankton wheel $(1 \mathrm{rpm})$ in front of a light source $\left(100 \mu \mathrm{E} \mathrm{m} \mathrm{m}^{-2} \mathrm{~s}^{-1}, 12 \mathrm{~h}\right.$ light:12 h dark cycle). The phytoplankton community exposed to $\mathrm{pH} 7.7,7.4$ and 7.1 was lowered in steps of $0.5 \mathrm{pH}$ units per $12 \mathrm{~h}$ by adding strongly acidified seawater with a $\mathrm{pH}$ of $4.9 \pm 0.1$ (Fig. 2; Day 0). After 24 h, all incubation bottles had reached their respective $\mathrm{pH}$ set points. To produce acidic seawater, 21 of $0.45 \mu \mathrm{m}$ filtered seawater were bubbled strongly with $\mathrm{CO}_{2}$ (ca. 5 min) and then with $\mathrm{O}_{2}$ (Hede Nielsen) (ca. $5 \mathrm{~s})$ to increase the concentration of $\mathrm{O}_{2}$ $>100 \%$, which was measured with a WTW Oxi 3210 oxygen meter using a WTW DurOx oxygen probe. During the remaining part of the experiment, the acidic seawater was added to bottles of $210.45 \mu \mathrm{m}$ filtered seawater to obtain seawater for dilution with the specific experimental $\mathrm{pH}$ values; 7.7, 7.4 and 7.1 (Fig. 2; Day 1 to end of experiment). Before each sampling, the acidic seawater and the $\mathrm{pH}$-specific seawater for dilution were produced as described. The phytoplankton community at pH 8.0 was used as a control, resembling the $\mathrm{pH}$ in Disko Bay at the time of sampling, and diluted with $0.45 \mu \mathrm{m}$ filtered seawater without adjustment of $\mathrm{pH}$. The treatment at $\mathrm{pH} 8.0$ was terminated on Day 11, while pH 7.7 and 7.4 were terminated on Day 17, and pH 7.1 on Day 16.

\section{Sampling and dilution}

The incubation bottles were removed in triplicates from the plankton wheel and kept cold in a cooling box filled with snow during sampling ( 20 min). The phytoplankton community was diluted throughout sampling and additional dilutions were done to avoid high biomasses that would cause large fluctuations in $\mathrm{pH}$ and nutrient limitation. First, $\mathrm{pH}$ was measured and samples were withdrawn. Then, the incubation bottles were refilled with $\mathrm{pH}$-specific seawater (dilution). If dilution was insufficient to obtain the experimental $\mathrm{pH}$, a few drops of acidic seawater were added. The phytoplankton community was always

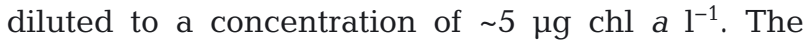
intensity of sampling depended on the growth rate of the phytoplankton community (using chl a as a proxy) and due to the extraction time of chl a the 

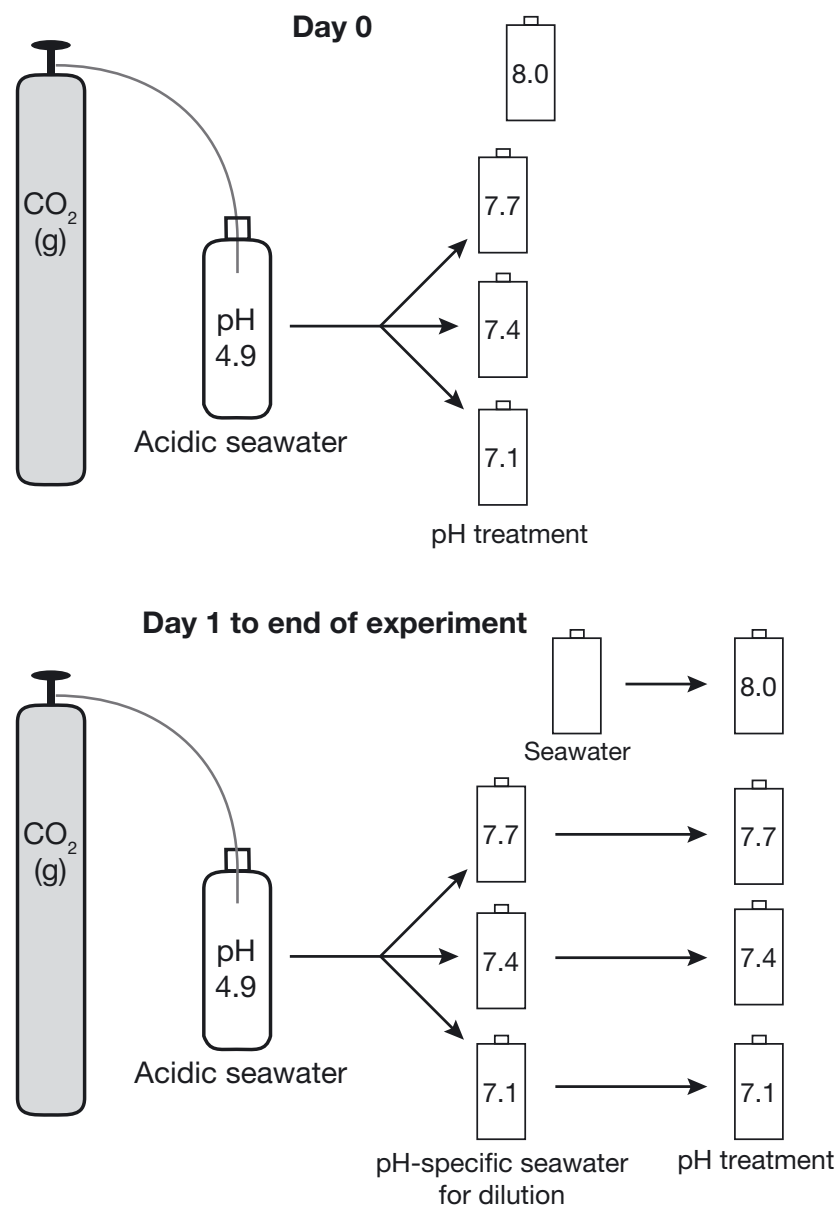

Fig. 2. Experimental setup. Day 0: Acidic seawater was used to reduce the $\mathrm{pH}$ treatments of the phytoplankton community to the respective $\mathrm{pH}$ levels, except the control, which remained at $\mathrm{pH}$ 8.0. Day 1 to end of experiment: $\mathrm{pH}$-specific seawater for dilution of the phytoplankton in the $\mathrm{pH}$ treatments was lowered to the respective $\mathrm{pH}$ levels with acidic seawater. The control treatment ( $\mathrm{pH}$ 8.0) was diluted with filtered seawater without adjustment of $\mathrm{pH}$

dilution to $\sim 5 \mu \mathrm{g} \mathrm{chl} \mathrm{a} \mathrm{l}^{-1}$ was an approximate estimate. The control treatment at $\mathrm{pH} 8.0$ was sampled nearly every day, while $\mathrm{pH} 7.7,7.4$ and 7.1 were sampled every $2^{\text {nd }}$ or $3^{\text {rd }}$ day. On Day 5 , the desired concentration of $5 \mu \mathrm{g} \mathrm{chl} \mathrm{a} \mathrm{l^{-1 }}$ was reached in all $\mathrm{pH}$ treatments and Day 0 to 5 was set as the period of acclimation (not included in the results).

\section{pH}

$\mathrm{pH}$ was measured with a WTW pH $3210 \mathrm{pH}$ meter equipped with a WTW SenTix 41 electrode. The electrode was calibrated using a 2-point calibration and regularly checked for correct measurements in buffers of pH 7 and 10 (WTW Technical Buffer, NIST scale). Prior to use ( $\geq 10 \mathrm{~min})$, the $\mathrm{pH}$ electrode was immersed in filtrated seawater to stabilize.

\section{DIC and nutrients}

Samples for DIC were fixed with $100 \mu \mathrm{Hg}_{2} \mathrm{Cl}_{2}$ (mercury(I)chloride) in airtight glass vials $(12 \mathrm{ml})$ without headspace to avoid $\mathrm{CO}_{2}$ leaking out of the water phase. Samples were stored in dark and cold conditions until measurements 1 mo later at Marine Biological Laboratorium in Helsingør, Denmark. Triplicate measurements were conducted on an IRGA (infrared gas analyzer) by comparing with a $\mathrm{HCO}_{3}{ }^{-}$(bicarbonate) standard of $2.0 \mathrm{mM}$ (for procedure see Nielsen et al. 2007). The carbon speciation $\left(\mathrm{HCO}_{3}{ }^{-}\right.$, $\mathrm{CO}_{3}{ }^{2-}$ and $\mathrm{CO}_{2}{ }^{*}$ [ ${ }^{*}$ includes $\mathrm{H}_{2} \mathrm{CO}_{3}$ and $\mathrm{CO}_{2}$ ]) was calculated using the program CO2SYS developed for $\mathrm{CO}_{2}$ system calculations (Lewis \& Wallace 1998).

Samples for measurements of the inorganic nutrients phosphate $\left(\mathrm{PO}_{4}{ }^{3-}\right)$, nitrate $\left(\mathrm{NO}_{3}{ }^{-}\right)$and silicate $\left(\mathrm{Si}(\mathrm{OH})_{4}\right)$ were transferred into plastic bottles $(35 \mathrm{ml})$ and frozen immediately. The samples were analyzed at the Institute for Bioscience, University of Aarhus, following the procedures of Grasshoff (1976) and Valderrama (1981).

\section{Chl a}

A 50 to $100 \mathrm{ml}$ sample of the phytoplankton community was filtrated through a $0.7 \mu \mathrm{m} \mathrm{GF} / F$ filter and a $10 \mu \mathrm{m}$ Nitex@ plankton gauze, respectively. Immediately afterwards, the filters were extracted in $5 \mathrm{ml}$ $96 \%$ ethanol in glass vials and stored in the dark at room temperature. The next day, chl a was measured on a TD-700 Fluorometer (Turner Designs) following Jespersen \& Christoffersen (1987). The growth rate of the phytoplankton community ( $\mathrm{chl}$ a) was calculated from the cumulative growth due to the dilution technique.

\section{Enumeration and identification of phytoplankton species}

Samples for enumeration of phytoplankton taxa $(120$ to $250 \mathrm{ml})$ were transferred to brown glass bottles $(250$ to $300 \mathrm{ml})$ containing acidic Lugol's iodine ( $2 \%$ final concentration) and stored in the dark at room temperature. Cells of dominating species were counted on an inverted microscope (Olympus CK40) 
Table 1. The dominant phytoplankton species from Disko Bay in this study. Enumeration of single cells, colonies or chains of the given species is indicated by ' $\mathrm{X}$ '. The presence of single cells of species which were not enumerated is indicated by '-'. Blanks indicate that colonies or chains are not formed by the species

\begin{tabular}{|llcc|}
\hline & Species & Single cells & Colonies/chains \\
\hline Diatoms & Thalassiosira spp. & $\mathrm{X}$ & $\mathrm{X}$ \\
& Chaetoceros spp. (incl. C. socialis) & $\mathrm{X}$ & $\mathrm{X}$ \\
& Navicula vanhoeffenii & $\mathrm{X}$ & $\mathrm{X}$ \\
& Navicula cf. granii & - & $\mathrm{X}$ \\
Navicula spp. (incl. N. transitans var. derasa f. delicatula) & - & $\mathrm{X}$ \\
Prymnesiophyte & Phaeocystis pouchetii & $\mathrm{X}$ \\
\end{tabular}

using 25 or $50 \mathrm{ml}$ sedimentation chambers (HydroBios) with $24 \mathrm{~h}$ settling time. A minimum of 400 cells or 6 transects were enumerated. Cells in colonies or chains, single cells, or both were enumerated (Table 1). The growth rate was calculated from the cumulative growth due to the dilution technique. Species were identified based on light microscopic characters using Tomas (1997), except for Navicula cf. granii which was identified using a JEOL-1010 transmission electron microscope (TEM; Jeol). Prior to identification by TEM, a sample of the phytoplankton community at $\mathrm{pH} 8.0$ was rinsed following Lundholm et al. (2002).

\section{Colony, chain and cell size}

The diameter of 25 random colonies of the prymnesiophyte Phaeocystis pouchetii was measured on an inverted microscope (Olympus CK40). The number of cells in the chains of the diatom species Thalassiosira spp., Navicula vanhoeffenii, Chaetoceros spp. and Navicula cf. granii were enumerated in 25 random chains. Single cells and chains $\geq 2$ cells were included for Thalassiosira spp., Navicula vanhoeffenii and Chaetoceros spp. Only chains $\geq 2$ cells were included for Navicula cf. granii due to difficulty identifying single cells on the inverted microscope.

\section{Calculations}

DIC speciation $\left(\mathrm{HCO}_{3}{ }^{-}, \mathrm{CO}_{3}{ }^{2-}\right.$ and $\left.\mathrm{CO}_{2}{ }^{*}\right)$ was calculated with the program CO2SYS and the following available inputs: Set of constants: K1, K2 from Mehrbach et al. (1973) refit by Dickson \& Millero (1987); KHSO4: Dickson; pH scale: Seawater (SW) scale $\left(\mathrm{mol} \mathrm{kg}^{-1} \mathrm{SW}\right)$. For further information about CO2SYS see Lewis \& Wallace (1998).
Dilution of the phytoplankton community ( $\mathrm{chl} a$ ) was calculated as:

$$
\mathrm{vol}_{\mathrm{r}}=\left(1-\frac{C_{2}}{C_{1}}\right) \cdot \mathrm{vol}_{\mathrm{t}}
$$

where $\mathrm{vol}_{\mathrm{r}}$ and $\mathrm{vol}_{\mathrm{t}}$ is the volume replaced with $\mathrm{pH}$ specific seawater and total volume of the incubation bottle, respectively, and $C$ is the chl a concentration before $\left(C_{1}\right)$ and after $\left(C_{2}\right)$ dilution.

Growth rate of the phytoplankton community (chl a) and species was calculated assuming exponential growth:

$$
\mu=\frac{\ln \left(\frac{N_{t 2}}{N_{t 1}}\right)}{t_{2}-t_{1}}
$$

where $\mu$ is the growth rate and $N$ is chl a or cell concentration at time $t_{2}$ and $t_{1}$. The cumulative concentration $\left(\mu^{\prime}\right)$ of chl $a$ and cells were calculated using $\mu$ due to the dilution technique:

$$
\mu^{\prime}=N_{t 1} \cdot \mathrm{e}^{\mu_{t 2} \cdot\left(t_{2}-t_{1}\right)}
$$

where $N$ is chl a or cell concentration and $\mu$ is the growth rate at time $t_{2}$.

The growth rate for a $\mathrm{pH}$ treatment was calculated as the average of the triplicate samples' linear regressions of $\ln$ (cumulative $\mathrm{chl}$ a concentration) or ln(cumulative cell concentration) after acclimation with the slopes equalling to the growth rates.

\section{Statistics}

Significant differences were analyzed using ANOVA (1-way) followed by pairwise multiple comparisons with the Holm-Sidak method. The null hypothesis $\left(H_{0}\right)$ was that there was no difference between $\mathrm{pH}$ treatments, and $H_{0}$ was rejected when $\mathrm{p}<0.05$. The significance level was set to 0.05 in all analyses. 


\section{RESULTS}

\section{Hydrography of sampling station in Disko Bay}

On the day of sampling (14 April 2012), the temperature and salinity of the surface water were $-1.6^{\circ} \mathrm{C}$ and 33.2 , respectively. At a depth of $300 \mathrm{~m}$, this increased to $3.6^{\circ} \mathrm{C}$ and 34.4 , respectively. A pycnocline at $160 \mathrm{~m}$ depth kept the spring bloom in the upper water column with a maximum chl a concentration of $1.4 \mathrm{\mu g}$ $\mathrm{l}^{-1}$ at $5 \mathrm{~m}$ depth (data not shown). The phytoplankton community was sampled from the maximum chl a where temperature, salinity and $\mathrm{pH}$ were $-1.4^{\circ} \mathrm{C}, 33.2$ and 7.9 , respectively. The vertical distribution of in situ $\mathrm{pH}$ at a water column depth of $250 \mathrm{~m}$ was measured during the spring of 2011 and 2012 (Fig. 3). In 2011, $\mathrm{pH}$ was not measured throughout the spring bloom but varied between 7.9 and 8.5 from the end of April to the end of May. In 2012, pH varied between 7.5 and 8.3 from the end of March to the end of May. In March 2012, pH in the water column was 7.8 for approx. 2 wk and increased during April. However, there was a decrease to $\mathrm{pH} 7.5$ in early April and mid-May. At the end of May, $\mathrm{pH}$ decreased for a longer period to 7.8 , with a small increase to $\mathrm{pH} 8.0$ in the upper part of the water column.

\section{Experimental pH, DIC and nutrients}

$\mathrm{pH}$ in the experimental treatments fluctuated minimally from the designated $\mathrm{pH}$ levels of 8.0, 7.7, 7.4 and 7.1 throughout the experimental period (Table 2). The concentration of DIC in the triplicate of each $\mathrm{pH}$ treatment was not significantly different between the midway point and the end of the experiment (Holm-Sidak, $\mathrm{p}>0.05$ ) (data not shown). DIC increased from $2222.2 \pm 2.3 \mu \mathrm{mol} \mathrm{kg}{ }^{-1}$ at $\mathrm{pH} 8.0$ to $2522.6 \pm$ $35.9 \mu \mathrm{mol} \mathrm{kg} \mathrm{kg}^{-1}$ at pH 7.1 (Table 2). The DIC concentration at $\mathrm{pH} 7.1$ was significantly different from the other $\mathrm{pH}$ treatments (HolmSidak, $\mathrm{p}<0.05)$. The carbon speciation of DIC in the $\mathrm{pH}$ treatments was dominated by bicarbonate ion $\left(\mathrm{HCO}_{3}^{-}\right)$at $>90 \%$, while the concentration of carbonate ion $\left(\mathrm{CO}_{3}{ }^{2-}\right)$ decreased and carbon dioxide $\left(\mathrm{CO}_{2}{ }^{*}\right)$ increased with lowered $\mathrm{pH}$. The concentration of $\mathrm{CO}_{3}{ }^{2-}$ and $\mathrm{CO}_{2}{ }^{*}$ was significantly different between all $\mathrm{pH}$ treatments (Holm-Sidak, $\mathrm{p}<0.05)$.

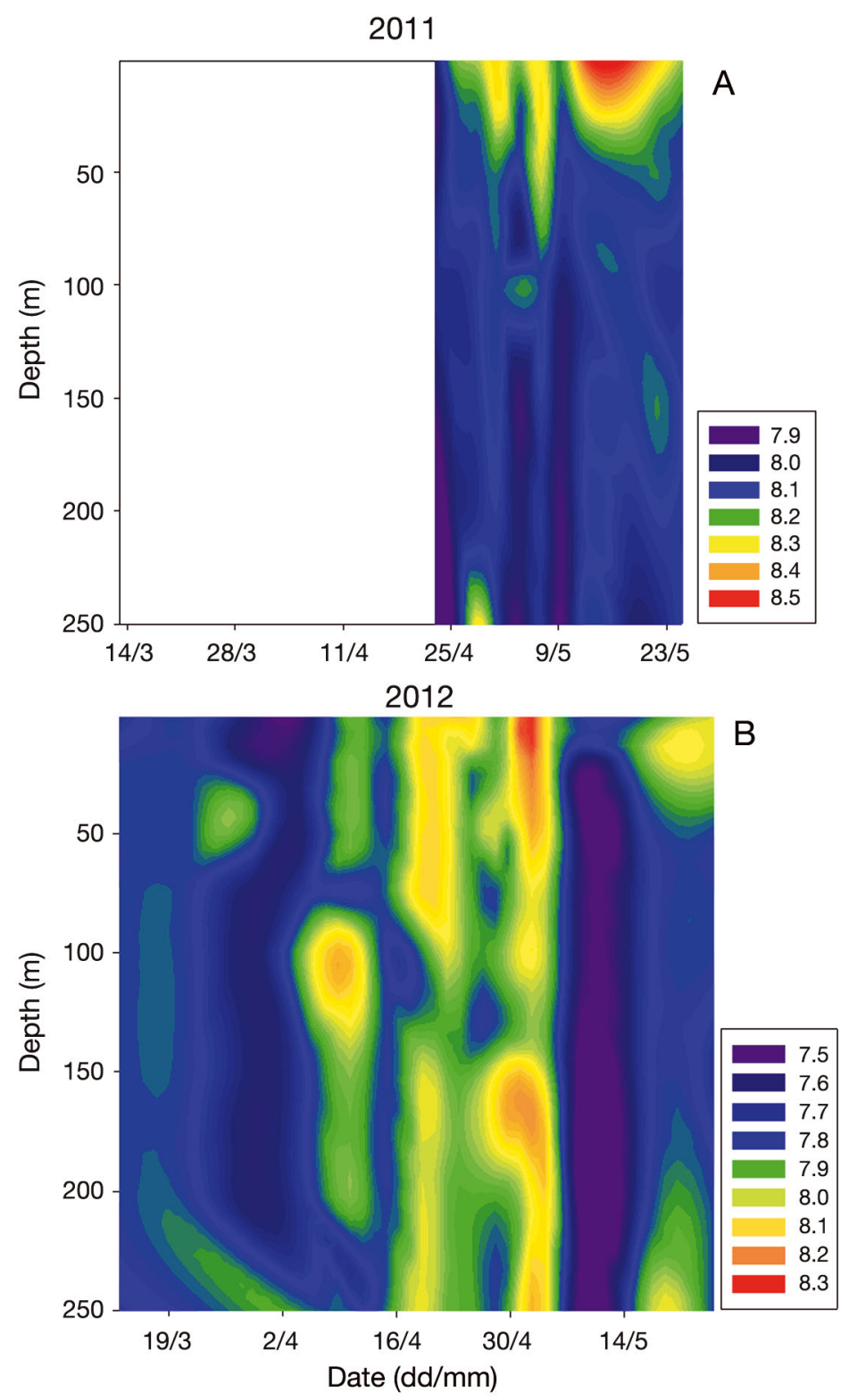

Fig. 3. In situ $\mathrm{pH}$ of Disko Bay. Vertical distribution of $\mathrm{pH}$ at the coastal sampling station at a depth of $250 \mathrm{~m}$ during (a) spring 2011 and (b) 2012

Table 2. Average $\mathrm{pH}$ in the experimental treatments from Day 1 to the end of the experiment $( \pm S D, n=3)$. The concentration of dissolved organic carbon (DIC) is the average of 2 sampling times (midway and at the end of the experiment). The carbon speciation of DIC is given in percent. *includes $\mathrm{H}_{2} \mathrm{CO}_{3}$ and $\mathrm{CO}_{2}$

\begin{tabular}{|ccccc|}
\hline $\mathrm{pH}$ & $\begin{array}{c}\mathrm{DIC} \\
\left(\mu \mathrm{mol} \mathrm{kg}{ }^{-1}\right)\end{array}$ & $\begin{array}{c}\mathrm{HCO}_{3}{ }^{-} \\
(\%)\end{array}$ & $\begin{array}{c}\mathrm{CO}_{3}{ }^{2-} \\
(\%)\end{array}$ & $\begin{array}{c}\mathrm{CO}_{2}{ }^{*} \\
(\%)\end{array}$ \\
\hline $8.01 \pm 0.04$ & $2222.2 \pm 2.3$ & $94.3 \pm 0.2$ & $4.7 \pm 0.3$ & $1.0 \pm 0.1$ \\
$7.71 \pm 0.04$ & $2286.4 \pm 8.8$ & $95.5 \pm 0.0$ & $2.3 \pm 0.0$ & $2.1 \pm 0.0$ \\
$7.44 \pm 0.04$ & $2341.7 \pm 40.0$ & $95.1 \pm 0.1$ & $1.4 \pm 0.1$ & $3.5 \pm 0.2$ \\
$7.15 \pm 0.05$ & $2522.6 \pm 35.9$ & $92.1 \pm 0.2$ & $0.6 \pm 0.0$ & $7.3 \pm 0.2$ \\
\hline
\end{tabular}


In situ concentrations of the nutrients $\mathrm{NO}_{3}{ }^{-}, \mathrm{PO}_{4}{ }^{3-}$ and $\mathrm{Si}(\mathrm{OH})_{4}$ at the depth of the chlorophyll maximum were $9.27 \pm 0.1 \mu \mathrm{M}, 0.77 \pm 0.01 \mu \mathrm{M}$ and $7.51 \pm 0.12$ $\mu \mathrm{M}$, respectively, and fitted the Redfield ratios of $16 \mathrm{~N}: 1 \mathrm{P}$ and $15 \mathrm{Si}: 16 \mathrm{~N}$. The nutrient concentrations in the $\mathrm{pH}$ treatments were not significantly different from the in situ concentrations throughout the experimental period (ANOVA, $\mathrm{p}>0.05$ ).

\section{Growth of the phytoplankton community}

The growth rate of the total phytoplankton community (i.e. chl $a>0.7 \mu \mathrm{m}$ ) was $0.50 \pm 0.01 \mathrm{~d}^{-1}$ at $\mathrm{pH} 8.0$ and decreased to $0.22 \pm 0.01 \mathrm{~d}^{-1}$ at $\mathrm{pH} 7.1$ (Fig. 4). The growth rate of the phytoplankton community $>10 \mu \mathrm{m}$ (i.e. chl $a>10 \mu \mathrm{m}$ ) was affected to the same degree but had a significantly higher growth rate at pH $8.0\left(0.58 \pm 0.02 \mathrm{~d}^{-1}\right), 7.7$ and 7.4. There was no significant difference between the growth rates of the total phytoplankton community and the phytoplankton community $>10 \mu \mathrm{m}$ at $\mathrm{pH} 7.1$ (Holm-Sidak, $\mathrm{p}<$ 0.05).

The phytoplankton community $>10 \mu \mathrm{m}$ was the dominating size fraction after Day 10 at $\mathrm{pH}$ 8.0, 7.7 and 7.4 (Fig. 5). In contrast, at $\mathrm{pH} 7.1$ the size fraction $>10 \mu \mathrm{m}$ did not exceed $40 \%$ during the experiment.

\section{Growth of the phytoplankton species}

In general, the highest growth rates of the phytoplankton species were obtained at $\mathrm{pH} 8.0$ and the lowest at $\mathrm{pH} 7.1$, but the growth rates differed among

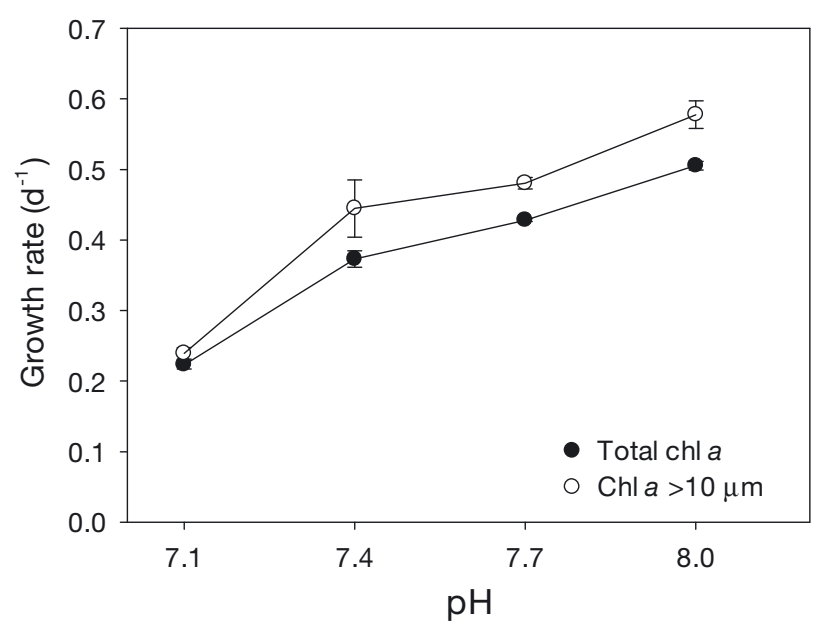

Fig. 4. Growth rate of the phytoplankton community at $\mathrm{pH}$ 8.0, 7.7, 7.4 and 7.1. Data points are means $\pm \mathrm{SD}(\mathrm{n}=3)$

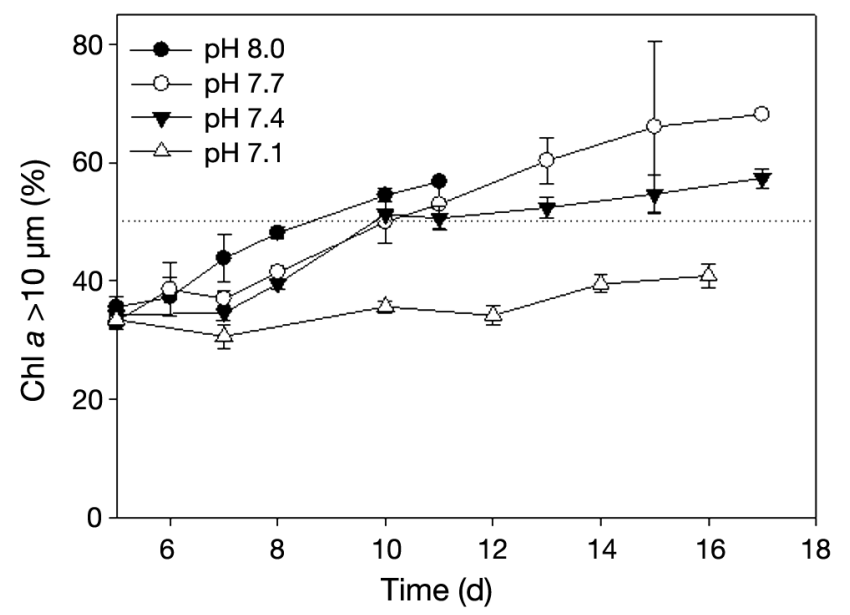

Fig. 5. Temporal size composition of the fraction of the phytoplankton community $>10 \mu \mathrm{m}$ at $\mathrm{pH}$ 8.0, 7.7, 7.4 and 7.1. Data points are means \pm SD $(n=3)$

species (Fig. 6). At $\mathrm{pH}$ 8.0, the growth rates of diatoms were the highest among the species $(\sim 0.4$ to $\sim 0.6 \mathrm{~d}^{-1}$ ), whereas the prymnesiophyte Phaeocystis pouchetii and the prasinophyte Pyramimonas sp. had lower growth rates $\left(\sim 0.3 \mathrm{~d}^{-1}\right)$. For all species, the growth rates at $\mathrm{pH} 7.1$ were significantly lower (>50\% compared to $\mathrm{pH} 8.0$ ), with few species not showing any growth at this $\mathrm{pH}$.

The effect of acidification on the growth rate was divided into 4 categories (Fig. 6): Category I, the species least affected. This was the prasinophyte Pyramimonas sp, and although there was a significant difference in growth rate between some of the $\mathrm{pH}$ treatments (Holm-Sidak, p < 0.05), a $32 \%$ reduction in growth rate from $\mathrm{pH} 8.0$ to 7.1 was the smallest compared to the other species. Category II, species not affected by acidification in the $\mathrm{pH}$ range 8.0 to 7.4. These comprised the diatom Navicula spp. and the prymnesiophyte $P$. pouchetii. At pH 7.1 neither species could sustain growth (Holm-Sidak, p < 0.05). Category III, species gradually affected by acidification. These were the chain-forming diatoms Thalassiosira spp., Navicula vanhoeffenii and Chaetoceros spp. with similar growth rates and a similar reduction in growth rate reaching $\sim 0.2 \mathrm{~d}^{-1}$ at $\mathrm{pH}$ 7.1. The growth rate for each species was not significantly different between pH 7.7 and 7.4 (Holm-Sidak, p > 0.05). Category IV, the species highly affected by acidification. This was the chain-forming diatom Navivula cf. granii, which had a significantly different growth rate for each $\mathrm{pH}$ treatment (Holm-Sidak, $p>0.05)$. This species had one of the highest growth rates at $\mathrm{pH} 8.0$ but was also the most sensitive species and could not sustain growth at $\mathrm{pH}$ 7.1. 

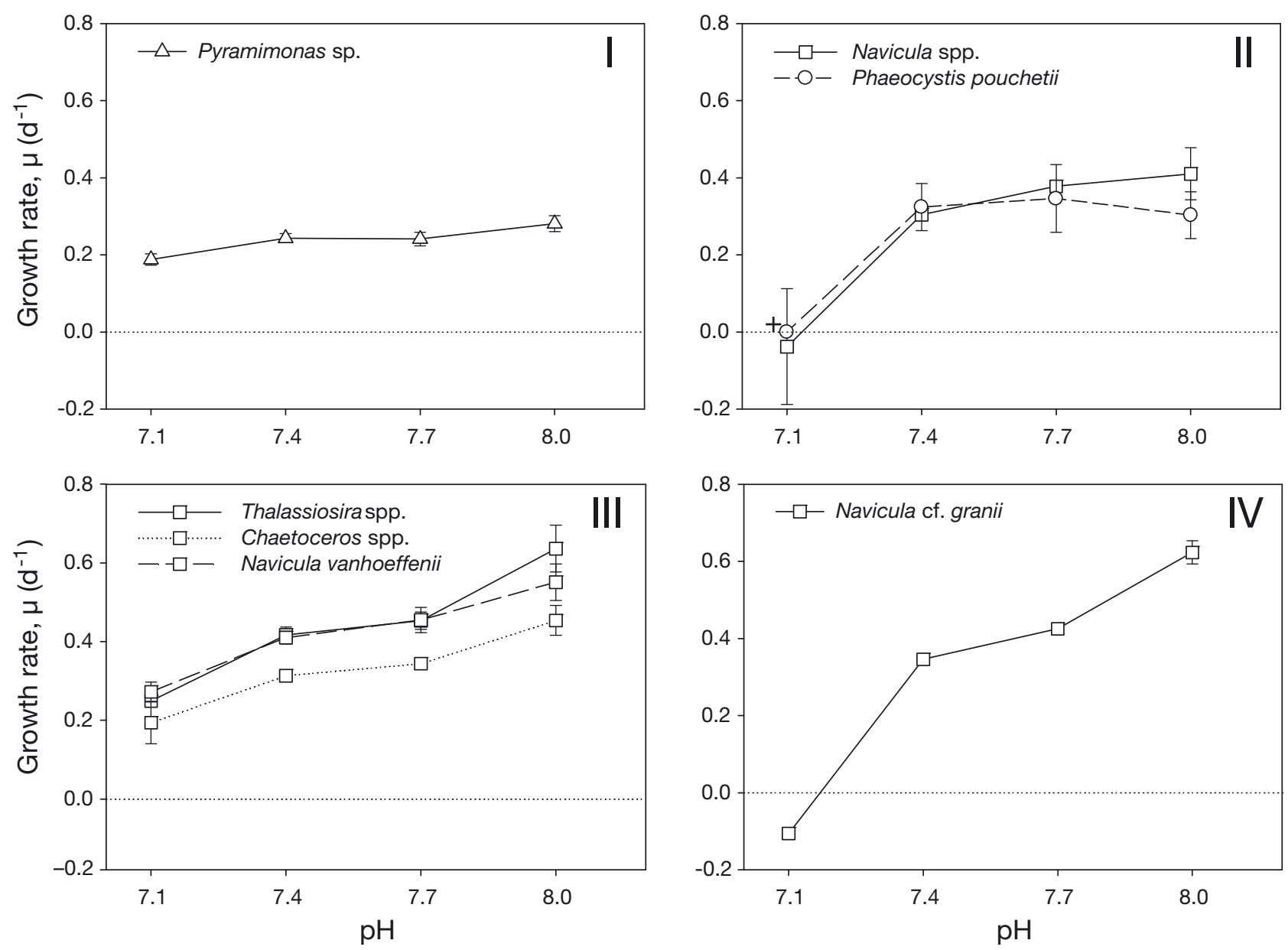

Fig. 6. Growth rates of phytoplankton species. The species were divided into categories based on their tolerance to acidification: least affected (I); affected only at pH 7.1 (II); gradually affected (III); and highly affected (IV). ( + ) indicates presence of Phaeocystis pouchetii colonies until Day 10 at $\mathrm{pH}$ 7.1. Data points are means $\pm \mathrm{SD}(\mathrm{n}=3)$

\section{Effect of acidification on colony size and chain length}

The colony size of Phaeocystis pouchetii was reduced during acidification (Fig. 7). On Day 5, the frequency of $P$. pouchetii colonies with a diameter of up to $280 \mu \mathrm{m}$ was similar at pH 8.0, 7.7 and 7.4, with a slight decrease in size with increasing acidification (only data for $\mathrm{pH} 8.0$ is shown). However, at $\mathrm{pH} 7.1 \mathrm{a}$ decrease in colony size was observed on Day 5 with the majority of colonies measuring up to $80 \mu \mathrm{m}$. Microscopical observations of $P$. pouchetii colonies at $\mathrm{pH} 7.1$ revealed that the cells were unorganized and clustered, making it impossible to enumerate the cells in the colonies after Day 5. After $10 \mathrm{~d}$ no $P$. pouchetii colonies were present at pH 7.1 (Fig. 6). Also, the chain length (i.e. no. of cells) of Thalassiosira spp. decreased with acidification (Fig. 8). At pH 8.0, the majority of chains contained up to 8 cells on
Day 11, compared to 4 cells at pH 7.1. A similar effect on chain length was observed for $N$. vanhoeffenii and Chaetoceros spp., while the chain length of $N$. cf. granii did not appear to be affected (data not shown).

\section{DISCUSSION}

\section{Fluctuations of pH in Disko Bay during spring}

Few data are available on fluctuations of $\mathrm{pH}$ in Arctic marine ecosystems and these mostly report the fluctuations in open surface waters. Data on $\mathrm{pH}$ from coastal regions of the Arctic have so far been completely lacking, but here we document prominent fluctuations from $\mathrm{pH} 7.5$ to 8.3 in a $250 \mathrm{~m}$ water column in Disko Bay during the spring bloom of 2012. These fluctuations resemble observations in other coastal areas, e.g. pH at $2 \mathrm{~m}$ depth in the upwelling 

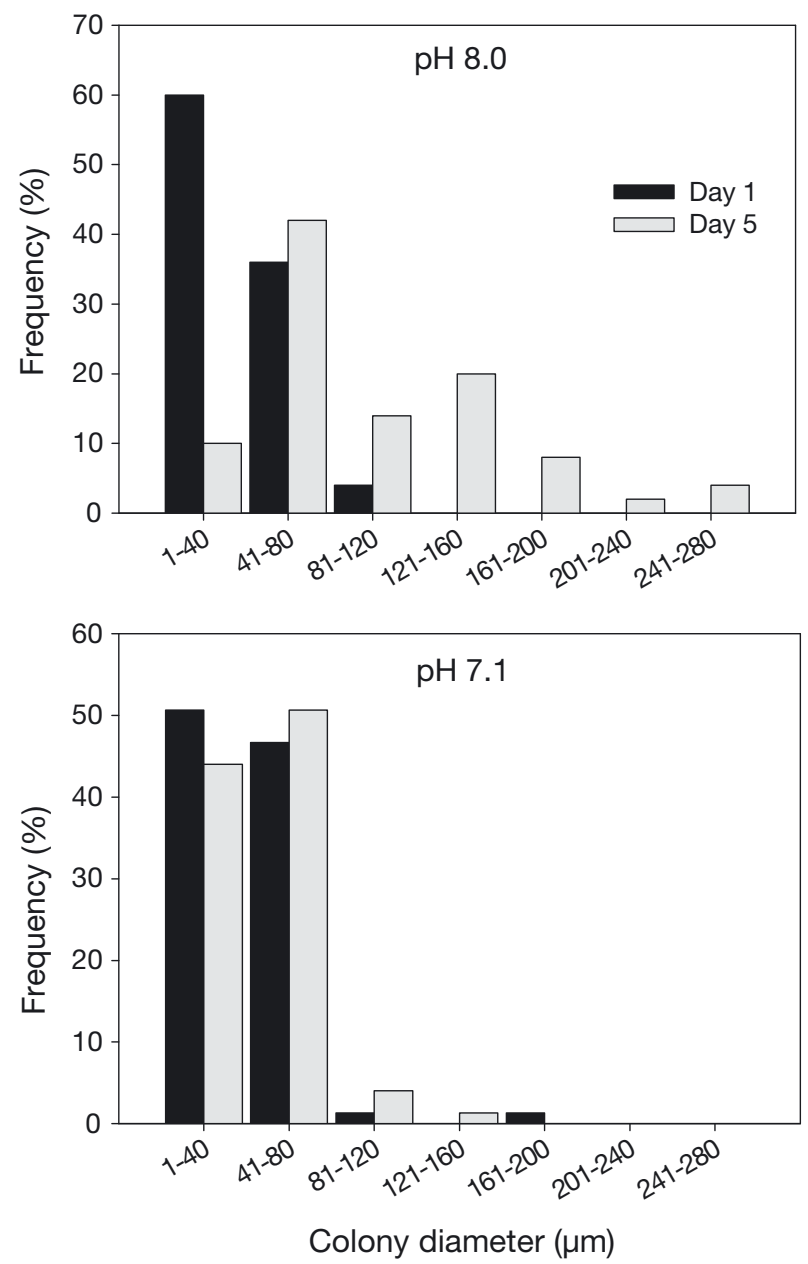

Fig. 7. Colony size. Frequency of the colony diameter of the prymnesiophyte Phaeocystis pouchetii at pH 8.0 and 7.1 on Days 1 and 5

area of Point Ano Nuevo, USA, varied from 7.7 to 8.1 over $30 \mathrm{~d}$ from mid-May (Hofmann et al. 2011) and $\mathrm{pH}$ in Narragansett Bay, USA, fluctuated from $~ 7.6$ to 8.5 over 1 yr at $5 \mathrm{~m}$ depth (Hinga 1992).

The observed $\mathrm{pH}$ fluctuations in Disko Bay were caused by several factors. Before the spring bloom, i.e. during the Arctic polar night and sea ice cover, with continuous lack of solar irradiance, there was a low $\mathrm{pH}$ at the sampling station due to the dominance of respiration processes. As the solar irradiance increased during the transition to polar day, factors such as chl $a$, photosynthesis and $\mathrm{pH}$ increased in the water column. Advection of sea ice into the bay reduced the solar irradiance into the water column and resulted in a decrease in $\mathrm{pH}$ twice during 2012 (early and mid-May) due to decreased photosynthesis and increased respiration (Fig. 3). $\mathrm{pH}$ in the water column was generally higher in 2011 compared to
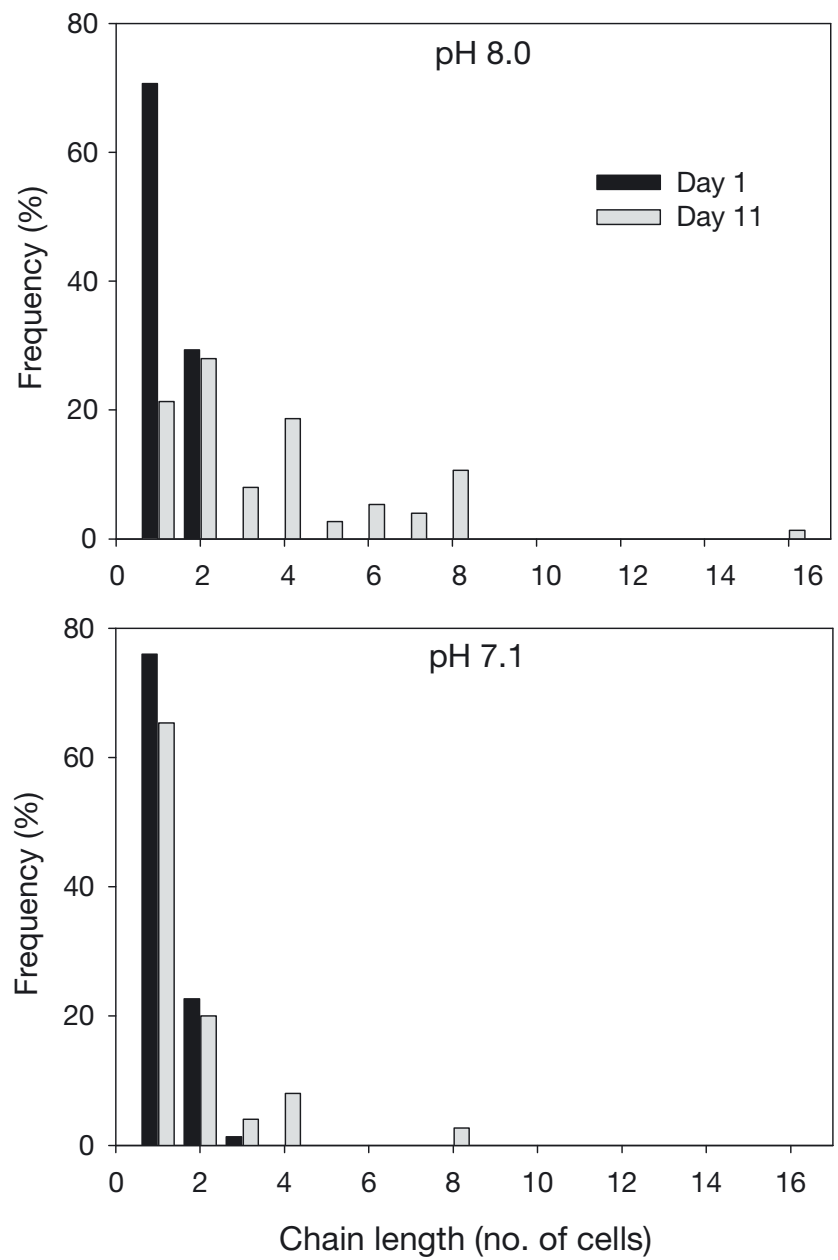

Fig. 8. Chain length. Frequency of the chain length (i.e. no. of cells) of the diatom Thalassiosira spp. at pH 8.0 and 7.1 on Days 1 and 11

2012 due to an earlier breakup of sea ice which allowed for a prolonged spring bloom ( $6 \mathrm{wk})$ with a longer period for photosynthesis to raise $\mathrm{pH}$ in the water column (T. G. Nielsen pers. obs.). On the day of sampling (14 April 2012), the salinity in the water column increased from the surface and downwards due to the melting of sea ice and a halocline was present at a depth of $\sim 160 \mathrm{~m}$, maintaining the photosynthetic plankton above this depth. Nutrients $\left(\mathrm{NO}_{3}{ }^{-}, \mathrm{PO}_{4}{ }^{3-}\right.$ and $\left.\mathrm{Si}(\mathrm{OH})_{4}\right)$ in the chlorophyll maximum $(5 \mathrm{~m})$ were plentiful at the time of sampling because the phytoplankton spring bloom had not yet peaked.

A pH below 7.5 was not measured in Disko Bay during spring but it is not unlikely that $\mathrm{pH}$ may decrease to values near 7.1 during the next centuries with ongoing ocean acidification. For instance, Wootton et al. (2008) found a significant decrease of $\mathrm{pH}$ in coastal waters on the Washington Shelf over a period 
of $8 \mathrm{yr}$ in association with increasing atmospheric $\mathrm{CO}_{2}$, and a similar acidification could likely be occurring in Disko Bay at present time.

\section{Nutrients, DIC and pH}

The nutrient concentrations of $\mathrm{Si}(\mathrm{OH})_{4}, \mathrm{NO}_{3}{ }^{-}$and $\mathrm{PO}_{3}{ }^{4-}$ in the experimental treatments exceeded those shown to be limiting for phytoplankton, including cold water species (e.g. Egge \& Aksnes 1992, Nelson \& Tréguer 1992). This excluded nutrient limitation as a cause for the decreasing growth rates during the experiment. The concentration of DIC and carbon speciation in the treatment at $\mathrm{pH} 8.0$ correlate well with literature data on ocean surface waters (e.g. Feely et al. 2009). At increased experimental acidification, the inorganic carbon availability, which could potentially benefit the autotrophic phytoplankton, was changed, theoretically, for the better with a vast concentration of $\mathrm{HCO}_{3}{ }^{-}$and increased $\mathrm{CO}_{2}$. However, a benefit from this inorganic carbon availability was not reflected in the phytoplankton growth rate. The $\mathrm{pH}$ of the treatments fluctuated minimally $(\leq 0.05$ units) throughout the experiment providing a valid response of the phytoplankton community to the experimental $\mathrm{pH}$ values.

\section{Effect of acidification on phytoplankton community growth rate}

The growth rate of the phytoplankton community from Disko Bay was affected negatively by the experimental acidification (Fig. 4), even for those communities grown within the range of in situ $\mathrm{pH}$ measured in Disko Bay in 2012 (pH 7.5 to 8.3). The effect was observed as a gradual decrease in community growth rate with decreasing $\mathrm{pH}$ from 8.0 to 7.1. Many studies have explored the effect of acidification on phytoplankton, but they tend to study the growth response within a narrow pH limit of 8.2 to 7.8 (e.g. Wang et al. 2010, Yang \& Gao 2012), probably because this reduction has been predicted to occur for open oceans by the end of the $21^{\text {st }}$ century. However, it is problematic to use such a narrow range of $\mathrm{pH}$ to study the tolerance of coastal phytoplankton to acidification because $\mathrm{pH}$ in coastal waters fluctuates within a larger range (as shown in this study). Furthermore, it is necessary to expose organisms to a $\mathrm{pH}$ lower than that measured in situ to evaluate the susceptibility of marine organisms to the ongoing ocean acidification.

\section{Effect of acidification on the growth rate of phytoplankton species}

The phytoplankton community in Disko Bay was dominated by diatoms, haptophytes and prasinophytes. The investigated species (Table 1) have previously been reported in Disko Bay (Nielsen \& Hansen 1999, DATMAPD marine protist database at www2.bio.ku.dk/disko/ [accessed 11.11.2012]) with the exception of Navicula cf. granii, in spite of this being a typical Arctic species (Guillard \& Kilham 1977). The ciliate species Strombidium sp. and Lohmaniella oviformis were also present in the $\mathrm{pH}$ treatments but due to a very low cell concentration the grazing by these ciliates on the phytoplankton is assumed to have been insignificant. The tolerance of marine protists to $\mathrm{pH}$ has previously been found to be species-specific (Tortell et al. 2002, Kim \& Lee 2006, Berge et al. 2010) and the present study supports this, as the phytoplankton species could be divided into 4 well-defined categories (Fig. 6). Studies show that prasinophytes are quite tolerant to acidification and actually increase in abundance, possibly due to a higher exploitation of the elevated $\mathrm{CO}_{2}$ levels (Meakin \& Wyman 2011, Newbold et al. 2012). The prasinophyte Pyramimonas sp. in the present study did not attain a higher growth rate during acidification. However, it was the species least affected and our study supports the proposal that prasinophytes may be fairly tolerant to acidification. Also the diatom Navicula spp. and the haptophyte Phaeocystis pouchetii were quite tolerant to acidification and were only affected at $\mathrm{pH}$ 7.1. P. pouchetii is very common in Arctic waters with colonies up to $2 \mathrm{~mm}$ in diameter (Schoemann et al. 2005) and the broad tolerance to acidification could be a contributing factor to the formation of the well-known large Phaeocystis blooms. However, the colony size of $P$. pouchetii was severely reduced at pH 7.1 (Fig. 7) and colonies disappeared after $10 \mathrm{~d}$. Normally, the cells in $P$. pouchetii colonies are embedded in groups of 4 but at pH 7.1 the cells were clustered. It is possible that low $\mathrm{pH}$ hampered the uptake or utilization of certain cations necessary for the mucus gelling in these colonies (van Boekel 1992). Only cells in colonies of $P$. pouchetii were enumerated so the present study did not clarify if single cells (4 to $7 \mu \mathrm{m}$; Schoemann et al. 2005) were either unable to tolerate a $\mathrm{pH}$ of 7.1 or if they were present but simply unable to form colonies.

Solitary species of the diatom genus Navicula are primarily benthic forms and common in sea ice from which they are released into the water column when 
the sea ice melts (Tomas 1997). In contrast to our study, where Navicula spp. could not sustain growth at $\mathrm{pH}$ 7.1, Wang et al. (1998) found a tolerance to acidification of benthic diatoms as growth rates decreased by merely $\sim 20 \%$ from $\mathrm{pH} 8.0$ to 7.0 . However, a comparison of the tolerance of species between different experiments is not optimal due to differences in experimental conditions and strains. Diatoms incorporate silicic acid $\left(\mathrm{Si}(\mathrm{OH})_{4}\right)$ into frustules during growth and this process is known to be negatively affected by acidification (Hervé et al. 2012). This could be a reason for the decreasing growth rates and chain lengths found in the present study. However, the single-celled diatom Navicula spp. was more tolerant to acidification than the chain-forming diatoms (Thalassiosira spp., Chaetoceros spp., $N$. vanhoeffenii and $N$. cf. granii), which suggests that chain-forming diatoms possess similar physiological mechanisms affected by acidification (Fig. 8), especially regarding chain elongation. Contrary to this, the chain length of $N$. cf. granii did not differ between $\mathrm{pH} 8.0$ and 7.1 although the growth rate was highly affected. The effect of acidification on the chain length of diatoms found in this study is unclear. The shorter chain lengths at low $\mathrm{pH}$ could simply be a result of lower growth rates of the diatoms obtained at $\mathrm{pH} 7.1$ as shown by Takabayashi et al. (2006), where changes in temperature and nutrient availability caused a lower growth rate and shorter chain lengths of the diatom Skeletonema costatum. However, all diatoms in the present study tolerated a $\mathrm{pH}$ range from 8.0 to 7.4 with either stable or reduced growth rates, and similar results were obtained from natural enclosures at Rhode Island, USA, where the frequency of diatoms was highest at the $\mathrm{pH}$ range $\sim 8.0$ to $\sim 7.4$ and decreased with acidification (Hinga 1992).

It is well known that voltage-gated $\mathrm{H}^{+}$channels in the plasma membrane of phytoplankton are extremely sensitive to changes in external $\mathrm{pH}\left(\mathrm{pH}_{\mathrm{e}}\right)$ (e.g. Taylor et al. 2012). The predicted drop in the average ocean surface water $\mathrm{pH}$ to $\sim 7.8$ by the end of this century (Feely et al. 2009) is thought to reverse the proton motive force, thereby impairing the passive efflux of $\mathrm{H}^{+}$out of the cell which regulates intracellular $\mathrm{pH}\left(\mathrm{pH}_{\mathrm{i}}\right)$. Changes in $\mathrm{pH}_{\mathrm{i}}$ studied by Hervé et al. (2012) with the diatom Thalassiosira weissflogii found that a lowering of $\mathrm{pH}_{\mathrm{e}}$ from 8.5 to 6.4 led to a drop in $\mathrm{pH}_{\mathrm{i}}$ from 7.6 to 6.7. This decrease in $\mathrm{pH}_{\mathrm{i}}$ may have severe physiological consequences, e.g. ion transport, enzyme activity and protein function, which will be reflected in reduced growth rates as observed in the present study (Gattuso \& Hansson
2011 and references therein, see also Nimer et al. 1994).

The phytoplankton species in the present study have been reported to also be present in the brine channels of Arctic sea ice (Abelmann 1992, Ikävalko \& Gradinger 1997, Werner et al. 2007, Niemi et al. 2011) where $\mathrm{pH}$ can vary from the surrounding $\mathrm{pH}$ of seawater up to $\mathrm{pH} 9.9$ (Gleitz et al. 1995). Thus, the phytoplankton is subjected to a $\mathrm{pH}$ as high as 9.9 in the brine of sea ice and as low as 7.5 in the water column (Fig. 3). This seasonal exposure to a broad $\mathrm{pH}$ range up to $2.4 \mathrm{pH}$ units could indicate that some Arctic phytoplankton species may be currently exposed to their potential maximum physiological range. This could explain why some species could not grow at $\mathrm{pH} 7.1$, a $\mathrm{pH}$ exceeding the natural fluctuations in Disko Bay during spring. In the present study, the phytoplankton appears to be more or less adapted to the natural fluctuations of $\mathrm{pH}$, leading to a broad tolerance to the experimental acidification between $\mathrm{pH} 8.0$ and 7.4. The species-specific tolerances to $\mathrm{pH}$ may contribute to the dominance of different species throughout the year as $\mathrm{pH}$ fluctuates. Three of 7 phytoplankton species were not able to grow at $\mathrm{pH} 7.1$, and if the $\mathrm{pH}$ in Disko Bay reaches pH 7.1 by the end of this century, a shift in the phytoplankton community structure may occur according to our results. Such a shift in species composition, colony size and chain length could affect the Arctic food web. Phaeocystis sp. is an important component of the phytoplankton in Arctic marine ecosystems, with a variety of grazers grazing on different sizes of Phaeocystis colonies (van Boekel 1992 and references therein, see also Tang 2003, Schoemann et al. 2005). In addition, the success of Phaeocystis blooms has been attributed to the ability to form large gelatinous colonies, and this study shows that the colonies were severely affected at $\mathrm{pH}$ 7.1. Hence, if colonies of $P$. pouchetii are inhibited by the ongoing acidification, they could become absent as an important food source for certain grazers, should the $\mathrm{pH}$ decrease to values near $\mathrm{pH} 7.1$.

\section{Is pH tolerance size-dependent?}

A size-dependent $\mathrm{pH}$ tolerance has been proposed for dinoflagellates and diatoms, with small species suggested to be able to tolerate a higher $\mathrm{pH}$ compared to larger species (Lundholm \& Hansen 2004, Søderberg \& Hansen 2007). The large surface:volume area in small species is thought to provide a better regulation of $\mathrm{pH}_{\mathrm{i}}$ during increased $\mathrm{pH}_{\mathrm{e}}$ and the 
same could apply for the tolerance to low $\mathrm{pH}$. However, considerable variations among species of similar sizes were also reported and a simulation study by Flynn et al. (2012) showed that large phytoplankton was better adapted to variable $\mathrm{pH}$ conditions compared to smaller sizes. In the present study, a sizedependent $\mathrm{pH}$ tolerance was found for the temporal composition of the phytoplankton community where large cells $(>10 \mu \mathrm{m})$ dominated at $\mathrm{pH} 8.0,7.7$ and 7.4 and small cells $(\leq 10 \mu \mathrm{m})$ dominated at pH 7.1 (Fig. 5). Similar results were obtained by Nielsen et al. (2010) for a coastal plankton community from Øresund Strait, Denmark, where large cells $(>15 \mu \mathrm{m})$ dominated at $\mathrm{pH} 8.0,7.8$ and 7.6 and small cells (10 to $15 \mu \mathrm{m}$ ) dominated at $\mathrm{pH}$ 6.0. Thus, small phytoplankton cells could be more tolerant to low $\mathrm{pH}$ ( $\mathrm{ca} \leq 7.1)$ compared to larger cells, but further research is needed to clarify the contrasting findings.

\section{Population genetic adaption and experimental acidification}

The present study was conducted over a short time span (17 d), which did not allow sufficient time for population genetic adaptation to the changing environment. The $\mathrm{pH}$ in treatments was adjusted from the in situ $\mathrm{pH}$ of Disko Bay (pH 7.9) to the experimental values of 7.7, 7.4 and 7.1 within $24 \mathrm{~h}$ and does not reflect the rate of ocean acidification occurring gradually over centuries. However, the present study shows the response of phytoplankton to the natural variations of $\mathrm{pH}$ in Disko Bay ( $\mathrm{pH} 7.5$ to 8.3), including some degree of tolerance when exposed to a low $\mathrm{pH}$ of 7.1. Several strains of a species are present within a natural assemblage, and population genetic adaption could potentially lead to the evolution of the strains which are more tolerant of low $\mathrm{pH}$. Thus, the effect of ocean acidification on phytoplankton might not be as significant as could be expected. However, such predictions are difficult to confirm, and studies of adaption are time-consuming. Few studies on adaption have been conducted; studies on the coccolithophores Emiliania huxleyi and Calcidiscus leptoporus suggest that adaption to acidification may in fact occur over time (Langer et al. 2006, Lohbeck et al. 2012).

Studies on the effect of acidification, using natural phytoplankton assemblages, need to take the time of year into consideration because seasonal distribution and diversity of species change over time due to variations of environmental conditions such as presence of sea ice, temperature, $\mathrm{pH}$ and salinity (von Quillfeldt
2000). Thus, if the present study had been conducted later in the season, it is likely that species composition and $\mathrm{pH}$ tolerance would have differed from the results obtained by the present study conducted in spring.

\section{CONCLUSIONS}

In situ $\mathrm{pH}$ in Disko Bay varied from 7.5 to 8.3 during the spring bloom in 2012, and the present study shows that the growth rate of the phytoplankton community decreased with $\mathrm{pH}$ within the in situ $\mathrm{pH}$ range. The phytoplankton community, as well as the investigated phytoplankton species, did not benefit from acidification despite abundant nutrients and inorganic carbon for growth and photosynthesis. A likely explanation could be that the phytoplankton growth is not limited by inorganic carbon at $\mathrm{pH} 8.0$ and/or that negative effects of lowered $\mathrm{pH}$ on physiological processes exceed the potentially beneficial effect of increased $\mathrm{CO}_{2}$. The study also reveals that a further decrease to $\mathrm{pH} 7.1$ may have severe effects on the productivity of the phytoplankton community. The response to acidification was species-specific, with some species being quite sensitive and others more tolerant. If future ocean acidification causes a decrease in $\mathrm{pH}$ in Disko Bay to 7.1 , a shift in the community structure and production may occur unless phytoplankton populations genetically adapt to the changing conditions over time.

Studies on the effect of ocean acidification should include the natural fluctuations of in situ $\mathrm{pH}$ in order to expose organisms from a specific site to an experimental $\mathrm{pH}$ range exceeding the natural fluctuations of $\mathrm{pH}$. In addition, information on genetic diversity within species, and how this potentially affects the species' response to acidification, is required.

Acknowledgements. The authors thank the helpful crew at Arctic Station in Qeqertarsuaq and the scientific crew involved in collecting data and analysing samples for this study. The authors are also grateful to the anonymous reviewers for their constructive critique. The project was funded by the European Commission FP7 EURO-BASIN (Grant Agreement: 264 933), a Freja stipend from the Faculty of Science, the Greenland Climate Research Centre (Project 6505), and the VKR Centre for Ocean Life.

\section{LITERATURE CITED}

Abelmann A (1992) Diatom assemblages in Arctic sea iceindicator for ice drift pathways. Deep-Sea Res II 39: S525-S538 
Berge T, Daugbjerg N, Balling Andersen B, Hansen PJ (2010) Effect of lowered $\mathrm{pH}$ on marine phytoplankton growth rates. Mar Ecol Prog Ser 416:79-91

Bergkvist J, Thor P, Jakobsen H, Wängberg SÅ, Selander E (2012) Grazer-induzed chain length plasticity reduces grazing risk in a marine diatom. Limnol Oceanogr 57: 318-324

Brutemark A, Engström-Öst J, Vehmaa A (2011) Long-term monitoring data reveal $\mathrm{pH}$ dynamics, trends and variability in the western Gulf of Finland. Int J Oceanogr Hydrobiol 40:91-94

> Duarte CM, Hendriks IE, Moore TS, Olsen YS and others (2013) Is ocean acidification an open-ocean syndrome? Understanding anthropogenic impacts on seawater $\mathrm{pH}$. Estuar Coasts 36:221-236

Egge JK, Aksnes DL (1992) Silicate as regulating nutrient in phytoplankton competition. Mar Ecol Prog Ser 83: 281-289

Feely RA, Sabine CL, Hernandez-Ayon JM, Ianson D, Hales B (2008) Evidence for upwelling of corrosive 'acidified' water onto the continental shelf. Science 320:1490-1492

Feely RA, Doney SC, Cooley SR (2009) Ocean acidification: present conditions and future changes in a high $\mathrm{CO}_{2}$ world. Oceanography 22:36-47

> Flynn JF, Blackford JC, Baird ME, Raven JA and others (2012) Changes in $\mathrm{pH}$ at the exterior surface of plankton with ocean acidification. Nat Clim Change 2:510-513

Gattuso JP, Hansson L (2011) Ocean acidification. Oxford University Press, New York, NY

Giordano M, Beardall J, Raven A (2005) $\mathrm{CO}_{2}$ concentrating mechanisms in algae: mechanisms, environmental modulation, and evolution. Annu Rev Plant Biol 56:99-131

Gleitz M, Loeff MR, Thomas DN, Dieckmann GS, Millero FJ (1995) Comparison of summer and winter inorganic carbon, oxygen and nutrient concentrations in Antarctic sea ice brine. Mar Chem 51:81-91

> Gradinger R (1996) Occurence of an algal bloom under Arctic pack ice. Mar Ecol Prog Ser 131:301-305

Grasshoff K (1976) Methods of seawater analysis. Verlag Chemie, Weinheim

Guillard RRL, Kilham P (1977) The ecology of marine planktonic diatoms. Botanical Monographs. University of California Press, Berkeley and Los Angeles, CA

Hansen PJ (2002) Effect of high pH on the growth and survival of marine phytoplankton: implications for species succession. Aquat Microb Ecol 28:279-288

Hervé V, Derr J, Douady S, Quinet M, Moisan L, Lopez PJ (2012) Multiparametric analyses reveal the pH-dependence of silicon biomineralization in diatoms. PLoS ONE 7:e46722

> Hinga KR (1992) Co-occurrence of dinoflagellate blooms and high $\mathrm{pH}$ in marine enclosures. Mar Ecol Prog Ser 86: 181-187

Hofmann GE, Smith JE, Johnson KS, Send U and others (2011) High-frequency dynamics of ocean pH: a multiecosystem comparison. PLoS ONE 6:e28983

Ikävalko J, Gradinger R (1997) Flagellates and heliozoans in the Greenland sea ice studied alive using light microscopy. Polar Biol 17:473-481

> Jakobsen HH, Tang KW (2002) Effects of protozoan grazing on colony formation in Phaeocystis globosa (Prymnesiophyceae) and the potential costs and benefits. Aquat Microb Ecol 27:261-273

Jespersen AM, Christoffersen K (1987) Measurements of chlorophyll-a from phytoplankton using ethanol as extraction solvent. Arch Hydrobiol 109:445-454

Kim JM, Lee K (2006) The effect of seawater $\mathrm{CO}_{2}$ concentration on growth of a natural phytoplankton assemblage in a controlled mesocosm experiment. Limnol Oceanogr 51: 1629-1636

Kooistra WHCF, Gersonde R, Medlin LK, Mann DG (2007) The origin and evolution of the diatoms: their adaption to a planktonic existence. In: Falkowski PG, Knoll AH (eds) Evolution of primary producers in the sea. Elsevier Academic Press, Amsterdam, p 207-250

Langer G, Geisen M, Baumann KH, Kläs J, Riebesell U, Thomas S, Young JR (2006) Species-specific responses of calcifying algae to changing seawater carbonate chemistry. Geochem Geophys Geosyst 7:Q09006, doi:10.1029/ 2005GC001227

Lewis E, Wallace DWR (1998) Program developed for $\mathrm{CO}_{2}$ system calculations. http://cdiac.ornl.gov/oceans/co2rprt. html (accessed 10 June 2012)

Lohbeck KT, Riebesell U, Reusch TBH (2012) Adaptive evolution of a key phytoplankton species to ocean acidification. Nat Geosci 5:346-351

> Lundholm N, Daugbjerg N, Moestrup Ø (2002) Phylogeny of the Bacillariaceae with emphasis on the genus Pseudonitzschia (Bacillariophyceae) based on partial LSU rDNA. Eur J Phycol 37:115-134

Lundholm N, Hansen PJ, Kotaki Y (2004) Effect of pH on growth and domoic acid production by potentially toxic diatoms of the genera Pseudo-nitzschia and Nitzschia. Mar Ecol Prog Ser 273:1-15

McCarthy A, Rogers SP, Duffy SJ, Campbell DA (2012) Elevated carbon dioxide differentially alters the photophysiology of Thalassiosira pseudonana (Bacillariophyceae) and Emiliania huxleyi (Haptophyta). J Phycol 48:635-646

> Meakin NG, Wyman M (2011) Rapid shifts in picoeukaryote community structure in response to ocean acidification. ISMEJ 5:1397-1405

> Middelboe AL, Hansen PJ (2007) High pH in shallow-water macroalgal habitats. Mar Ecol Prog Ser 338:107-117

> Nelson DM, Tréguer P (1992) Role of silicon as a limiting nutrient to Antarctic diatoms: Evidence from kinetic studies in the Ross Sea ice-edge zone. Mar Ecol Prog Ser 80:255-264

Newbold LK, Oliver AE, Booth T, Tiwari B and others (2012) The response of marine picoplankton to ocean acidification. Environ Microbiol 14:2293-2307

Nielsen TG, Hansen BW (1999) Plankton community structure and carbon cycling on the western coast of Greenland during the stratified summer situation. I. Hydrography, phytoplankton and bacterioplankton. Aquat Microb Ecol 16:205-216

Nielsen LT, Lundholm N, Hansen PJ (2007) Does irradiance influence the tolerance of marine phytoplankton to high $\mathrm{pH}$ ? Mar Biol Res 3:446-453

Nielsen LT, Jakobsen HH, Hansen PJ (2010) High resilience of two coastal plankton communities to twenty-first century seawater acidification: evidence from microcosm studies. Mar Biol Res 6:542-555

Niemi A, Michel C, Hille K, Poulin M (2011) Protist assemblages in winter sea ice: setting the stage for the spring ice algal bloom. Polar Biol 34:1803-1817

Nimer NA, Brownlee C, Merret MJ (1994) Carbon dioxide availability, intracellular $\mathrm{pH}$ and growth rate of the coccolithophore Emiliana huxleyi. Mar Ecol Prog Ser 109: $257-262$ 
Provoost P, van Heuven S, Soetaert K, Laane RWPM, Middelburg JJ (2010) Seasonal and long-term changes in $\mathrm{pH}$ in the Dutch coastal zone. Biogeosciences 7:3869-3878

Riebesell U, Kortzinger A, Oschlies A (2009) Sensitivities of marine carbon fluxes to ocean change. Proc Natl Acad Sci USA 106:20602-20609

Riebesell U, Fabry VJ, Hansson L, Gattuso JP (2010) Guide to best practices for ocean acidification research and data reporting. Publications Office of the European Union, Luxemburg. www.epoca-project.eu/index.php/guide-tobest-practices-for-ocean-acidification-research-and-datareporting.html

Rost B, Zondervan I, Wolf-Gladrow D (2008) Sensitivity of phytoplankton to future changes in ocean carbonate chemistry: current knowledge, contradictions and research directions. Mar Ecol Prog Ser 373:227-237

Schoemann V, Becquevort S, Stefels J, Rousseau V, Lancelot C (2005) Phaeocystis blooms in the global ocean and their controlling mechanisms: a review. J Sea Res 53: 43-66

Slagstad D, Ellingsen IH, Wassmann P (2011) Evaluating primary and secondary production in an Arctic Ocean void of summer sea ice: an experimental simulation approach. Prog Oceanogr 90:117-131

Smayda TJ, Bolelyn BJ (1966) Experimental observations on the flotation of marine diatoms, II. Skeletonema costatum and Rhizosolenia setigera. Limnol Oceanogr 11:18-34

Søderberg LM, Hansen PJ (2007) Growth limitation due to high $\mathrm{pH}$ and low inorganic carbon concentrations in temperate species of the dinoflagellate genus Ceratium. Mar Ecol Prog Ser 351:103-112

Takabayashi M, Lew K, Johnson A, Marchi A, Dugdale R, Wilkerson FP (2006) The effect of nutrient availability and temperature on chain length of the diatom, Skeletonema costatum. J Plankton Res 28:831-840

Tang KW (2003) Grazing and colony size development in Phaeocystis globosa (Prymnesiophyceae): the role of a chemical agent. J Plankton Res 25:831-842

Taylor AR, Brownlee C, Wheeler GL (2012) Proton channels

Editorial responsibility: Steven Lohrenz, New Bedford, Massachusetts, USA in algae-reasons to be excited. Trends Plant Sci 17: 675-684

Tomas CR (1997) Identifying marine phytoplankton. Academic Press, San Diego, CA

Tortell PD, DiTullio GR, Sigman DM, Morel FMM (2002) $\mathrm{CO}_{2}$ effects on taxonomic composition and nutrient utilization in an Equatorial Pacific phytoplankton assemblage. Mar Ecol Prog Ser 236:37-43

> Valderrama JC (1981) The simultaneous analysis of total nitrogen and total phosphorus in natural waters. Mar Chem 10:109-122

> van Boekel WHM (1992) Phaeocystis colony mucus components and the importance of calcium ions for colony stability. Mar Ecol Prog Ser 87:301-305

von Quillfeldt, CH (2000) Common diatom species in Arctic spring blooms - their distribution and abundance. Bot Mar 43:499-516

> Wang Q, Li M, Wang S, Ding M, Li Y, Cheng A (1998) Studies on culture conditions of benthic diatoms for feeding abalone. II. Effects of salinity, pH, nitrogenous and phosphate nutrients on growth rate. Chin J Oceanol Limnol 16:78-83

Wang Y, Smith WO, Wang X, Li S (2010) Subtle biological responses to increased $\mathrm{CO}_{2}$ concentrations by Phaeocystis globosa Scherffel, a harmful algal bloom species. Geophys Res Lett 37:L09604

> Werner I, Ikävalko J, Schünemann H (2007) Sea-ice algae in Arctic pack ice during late winter. Polar Biol 30: 1493-1504

> Wootton JT, Pfister CA, Forester JD (2008) Dynamic patterns and ecological impacts of declining ocean $\mathrm{pH}$ in a highresolution multi-year dataset. Proc Natl Acad Sci USA 105:18848-18853

Yang G, Gao K (2012) Physiological responses of the marine diatom Thalassiosira pseudonana to increased $\mathrm{pCO}_{2}$ and seawater acidity. Mar Environ Res 79:142-151

Zeebe RE, Wolf-Gladrow D (2003) $\mathrm{CO}_{2}$ in seawater: equilibrium, kinetics, isotopes. Elsevier Oceanography Vol 65. Elsevier, Amsterdam

Submitted: August 12, 2013; Accepted: November 14, 2014 Proofs received from author(s): January 14, 2015 